\title{
Functional Processed Cheese Spreads with High Nutritional Value as Supplemented with Fresh and Dried Mushrooms
}

\author{
Manal Khider ${ }^{1, *}$, Osama Seoudi ${ }^{2}$, Yasser Fathy Abdelaliem ${ }^{2}$ \\ ${ }^{1}$ Department of Dairy Science, Faculty of Agriculture, Fayoum University, Fayoum, Egypt \\ ${ }^{2}$ Department of Agric. Microbiol., Fac. of Agric., Fayoum Univ., Fayoum, Egypt
}

Email address:

mqa00@fayoum.edu.eg (M. Khider)

*Corresponding author

\section{To cite this article:}

Manal Khider, Osama Seoudi, Yasser Fathy Abdelaliem. Functional Processed Cheese Spreads with High Nutritional Value as Supplemented with Fresh and Dried Mushrooms. International Journal of Nutrition and Food Sciences. Vol. 6, No. 1, 2017, pp. 45-52. doi: $10.11648 /$ j.ijnfs.20170601.18

Received: December 26, 2016; Accepted: January 5, 2017; Published: January 23, 2017

\begin{abstract}
In this study processed cheese was supplemented with either fresh or dried edible mushroom (Pleurotus ostreatus Hk 35), to improve its nutritional value, functional and sensory properties, chemical composition, amino acids content, and microbiological quality. Fresh mushroom was added to cheese blend in pieces and smashed form at levels of 0, 5, 10 and $15 \%$, while dried mushroom was added at levels of $0,1,1.5$ and $2 \%$. Among all processed cheese treatments obvious differences $(\mathrm{P} \leq 0.01)$ were noticed in the organoleptic scores; the highest flavor scores $(37.4,37.3)$ were recorded for processed cheese supplemented with $1 \%$ and $1.5 \%$ mushroom powder, respectively. Significant differences $(\mathrm{P} \leq 0.01)$ were also recorded among chemical composition of the resulted processed cheese spreads. Moisture, ash and protein recorded the highest values in processed cheese supplemented with mushrooms compared to control. Moisture content in processed cheese control was $46.26 \%$, while ranged from 47.39 to $53.72 \%$ in cheese spread supplemented with mushrooms. There was a significant difference ( $\mathrm{P} \leq 0.001)$ in ash content of processed cheese spreads; the highest ash content $(5.4 \%)$ was for processed cheese spread supplemented with $2 \%$ dried mushroom. Cheese spreads that contain mushrooms was high in protein/DM (31.20$36.36 \%)$ comparing to the spread of control $(30.88 \%)$. There was also a significant difference $(\mathrm{P} \leq 0.001)$ in the contents of all tested minerals in processed cheeses. The highest mean values of $\mathrm{Ca}, \mathrm{P}, \mathrm{Mg}$ and $\mathrm{Zn}$ was observed in control and processed cheese that contain mushroom powder. Regarding the $\mathrm{pH}$ values; processed cheese spreads that contain mushrooms have $\mathrm{pH}$ values ranged from 5.39-5.78, while in control ranged from 5.47-5.63. Microbiological investigation showed that the total viable counts and spore former bacteria was lower in processed cheese supplemented with mushrooms than in cheese control. On the other hand, an increase in lipolytic and proteolytic bacteria was noticed during storage period. No yeast and molds were detected in the first month of storage for all processed cheese treatments.
\end{abstract}

Keywords: Functional Processed Cheese Spread, Nutritional Value, Amino Acids, Microbiological Analysis, Lipolytic and Proteolytic Bacteria

\section{Introduction}

Processed cheese is an attractive product that enjoys great popularity, [1]; this can be attributed to its numerous end-use applications, such in various food preparations [2], during the last decade the consumption of processed cheese spread was increased markedly in Egypt [3]. Processed cheese is a dairy product, produced by melting and emulsifying cheese via a thermal process, which increase the shelf life of natural cheese and find alternative uses for natural cheese that was difficult to sell [2]. However, this type of cheese is produced by blending natural cheese of different ages and degrees of maturity with water in different amounts. The cheeses were grated and mixed with milk fat, milk proteins, milk solids and emulsifying salts, which mostly is sodium citrates, sodium orthophosphates or sodium polyphosphates. It is also 
common to add other dairy and nondairy ingredients as desired or flavoured by a supply of aroma ingredients of animal (salami, smoked beef, sea foods, fish, salmon and prawns, etc.) or plant (vegetables like mushrooms, spices, herbs, and fruits, etc.), also colouring agents could be used, these food additives are sometimes added in the beginning of the process or by the end of it. Pasteurization of the additives occur if added in the beginning of the process, but on the other hand susceptible foods such mushrooms, tomatoes, sardine, shrimps and fruits, etc. can be badly bruised by agitation in the cooker. Additives must be added in the end of the process when cheese is homogenized [2, 4-6]. Different types of proteins, fat, gums, stabilizers, and minerals also could be added [7], followed by heating the cheese blend and continuous mixing to form a homogeneous product with an extended shelf life [2, 4, 5]. Processed cheese is not a preserved food, but a 'semi-preserved food' with limited shelf life of 3-4 months, especially when the product is packaged in plastic foils, while products stored in metal cans may have longer shelf lives of 6-12 months at room temperature [5]. Chemical composition of processed cheese as reported by many investigators was as following: protein 12.82-22.6, moisture 38.2-64.21\%, ash 1.33-4.82, titratable acidity 1.33-1.60 and $\mathrm{pH}$ 4.4-6.3 depending on the ingredients used in the manufacture of cheese [8-11].

Since earliest time mushrooms were considered as a special kind of food, the proximate composition of the commonly cultivated mushrooms reveals that edible mushrooms are rich in crude protein [12], carbohydrates and moderate in crude fiber, ash and low in fat content. Mushrooms an amazing natural food supplement [13], it contain many things that fit the definition of food supplements they are rich sources of many things that are important to our health. They are a good source of proteins that are important to all body functions. Their proteins are of very high quality and are rich in essential amino acids. They are also an excellent source of most B vitamins and the primary natural source of ergosterol or pro-vitamin D. People who eat balanced diets receive all of the needed minerals, but others get more sodium than they need. Mushrooms have the double benefit of low sodium and more potassium and iron than most foods. Chitin is the primary structural material in mushrooms and has been shown to be of value as dietary fiber, it can also be hydrolyzed to glucosamine, which is widely accepted by orthopedic physicians as a valuable food supplement for the prevention and alleviation of osteoarthritis [14]. They are a good source of vitamins, minerals [15] and essential amino acids; of these lysine is the most abundant [16] while, tryptophan and methionine are low. Mushroom contains also unsaturated fatty acids which it is essential in our diet and it represents $72 \%$ of the total fatty acids. Linoleic acid is found in mushroom in high amount and that is a significant factor in regarding mushrooms as a healthy food [7] also cholesterol lowering [15]. Mushroom also contains polysaccharide in the fruit bodies and that has the ability to inhibit growth of tumors. Mushrooms have become attractive as a functional food and as a source for the development of drugs and nutraceuticals responsible with their antioxidant, antitumor and antimicrobial properties. Besides their pharmacological features, mushrooms are becoming more important in our diet due to their nutritional value [17]. P. ostreatus mushroom possesses antioxidants activity mainly due to presence of polysaccharide pleuran and phenolic compounds; thereby reducing oxidative damage in humans due to their high free radical scavenging property [18]. Mushrooms have been proved to be one of the most productive sources producing a large and diverse variety of bioactive metabolites with significant antimicrobial activities. The medicinal bioactive compounds present in mushroom includes: polysaccharides, lipopolysaccharides, proteins, peptides, glycoproteins, nucleosides, tri-terpenoids, lectins, lipids and their derivatives. The antimicrobial properties of certain mushrooms provide human disease control that is generally safe and effective. Several mushrooms have demonstrated efficient antibacterial activity as well as antifungal activity against resistant human pathogens. Pleurotus ostreatus has been explored to combat simple and multiple drug resistant isolates of Eschrichia coli, Staphylococcus epidermidis, S. aureus and species of Candida Streptococcus, Enterococcus [13, 19, 20].

This study aim to evaluate the effect of fresh and dried mushrooms incorporated in the processed cheese to enhance the nutritional value, and functional properties by increasing the fiber contents and also improve its quality and organoleptic properties.

\section{Material and Methods}

Ras cheese (one and 8 month old), was obtained from small factory for cheese production in Fayoum, Egypt. Butter was obtained from pilot in Faculty of Agriculture, Fayoum University, Egypt. Low heat skim milk powder Grade A from Dairy American distributer (made in U. S. A.). The emulsifier used was a commercial mixture of two types; S20: B3 with a ratio of, 3:1.5, respectively. Fresh mushroom (Pleurotus ostreatus HK35) was cultivated in private mushroom farm, Agriculture Recycling Unit, Faculty of Agriculture, Fayoum University, Egypt. Pure culture of Pleurotus ostreatus HK35 was grown on Potato Dextrose Agar medium at $25^{\circ} \mathrm{C}$ for 21 days before used as inoculation.

\subsection{Experimental Procedure}

\subsubsection{Fresh Mushroom Preparation}

Fresh edible mushroom (Pleurotus ostreatus HK35) was prepared before use according to the method described by Fatma, et al. (2005) [6]. The whole fresh mushroom (FM) was immersed in $0.1 \mathrm{M}$ citric acid for $1 \mathrm{hr}$. at ambient temperature, and then cut to tiny pieces and soaked for another $10 \mathrm{~min}$. in $0.1 \mathrm{M}$ citric acid. After that mushroom was filtered from citric acid and boiled in water contain $1 \%$ of emulsifying salts for 15 min before use. Mushroom pieces were divided into two parts one part was mixed with cheese blend and the other part first smashed and then mixed with cheese blend. The major composition of fresh mushroom 
was, $88 \%, 4.8 \%, 0.994 \%$ for moisture, protein and ash content, respectively. Moreover, Mineral contents of fresh mushroom were, $120.34,34.90,13.26,7.56,0.33$ and $0.073 \mathrm{mg} / 100 \mathrm{~g}$ for $\mathrm{K}, \mathrm{P}, \mathrm{Ca}, \mathrm{Mg}, \mathrm{Fe}$ and $\mathrm{Zn}$, respectively.

\subsubsection{Dried Mushroom Preparation}

Mushroom powder (Pleurotus ostreatus HK35) was prepared according to a previous study by Khider, et al. (2015) [21]. The major composition of prepared mushroom powder (MP) was $7.27 \%$ moisture, $25 \%$ protein $/ \mathrm{DM}$ and $6.68 \%$ ash. Minerals content of mushroom powder ash was $2943.35,893.08,248.03,68.17,13.63$ and $4.94 \mathrm{mg} / 100 \mathrm{~g}$ of dry matter, for $\mathrm{K}, \mathrm{P}, \mathrm{Mg}, \mathrm{Ca}, \mathrm{Fe}$ and $\mathrm{Zn}$, respectively.

\subsection{Manufacture Procedure of Processed Cheese}

The processed cheese was manufactured according to the method described by Meyer (1973) [22]. Cheese blend: Fresh (one month) and matured Ras cheese (8 month) was grated and mixed with butter, low skim milk powder, water and emulsifier $(2.5 \%)$, then cooked at $85-90^{\circ} \mathrm{C}$ for $8 \mathrm{~min}$. In case of supplemented treatments; fresh and dried mushrooms were added by the end of cooking process. Afterwards, the spreads cooled to $60 \mathrm{C}$ and placed in polypropylene containers and stored at $7 \pm 2{ }^{\circ} \mathrm{C}$ for different analysis. The processed cheese spread treatments were as follow:

T1: Cheese blend (Control), T2- T7: Cheese blend + 5, 10 and $15 \%$ of Fresh mushrooms pieces or smashed, respectively. T8-T10: Cheese blend $+1,1.5$ and $2 \%$ Mushroom powder, respectively.

\subsection{Chemical Analysis}

A sample of previous treatments was taken for chemical analysis when fresh, and at 15,30 and 60 days. Moisture content, Total nitrogen and ash analysis were determined according to AOAC (2000) [23]. Values of $\mathrm{pH}$ for processed cheese samples were measured according to Peláez et al., (2003) [24] using pH meter Thermo Scientific Orion Star (A214). Total nitrogen in fresh processed cheese spreads were determined by Kjeldahl method, using Gerhardt equipment, type VAP 200 (Germany). Ash of processed cheese samples were incinerated at $550 \pm 1^{\circ} \mathrm{C}$, elements content of fresh processed cheese spreads ash was determined using Inductively Coupled Plasma (ICP) equipment (Model 6300 Duo UK, England); according to APHA, AWWA, and WEF (2005) [25]. Total amino acids were determined in fresh processed cheese spreads according to Official methods of analysis of AOAC (2012) [26], the analysis was conducted by Regional Center for Food and Feed, Agriculture Research Center, (Egypt).

\subsection{Organoleptic Properties}

Fresh processed cheese spread samples were served after manufacturing, at room temperature $\left(28^{\circ} \mathrm{C}\right)$ to evaluate the organoleptic properties by the stuff members of Dairy Science Department, Fayoum University, Egypt.

The score card was designed in the light of the score card suggested by the scheme of Meyer (1973) [22] as follows: Processed cheese flavor (40 points), body and texture (40 points), colour and appearance (20 points), which give total score of (100 points). Experimental data were statistically analyzed using general linear models of SPSS (1999) [27]. Mean of the values, were compared with main effects by Duncan's multiple range tests [28] when significant $F$ values were obtained $(\mathrm{P} \leq 0.01)$.

\subsection{Microbiological Examination}

Samples of all processed cheese spread were prepared for microbiological examination according to (Marshall, 1992) [29]. Ten grams of processed cheese was added to $90 \mathrm{ml}$ of warm sterile distilled water under sterilized conditions and then smashed for two minutes in a sterilized mortar. Further decimal dilutions were prepared in sterile distilled water. The samples were examined for total viable bacteria, spore forming bacteria, proteolytic, lipolytic bacteria and yeasts \& moulds count at $0,7,15,30$ and 90 day intervals. The media used were in a dehydrated form and prepared according to the manufacturer's instructions. Total viable bacteria were enumerated by pour plate method using standard plate count agar $[30,31]$ and the plates were incubated at $35^{\circ} \mathrm{C}$ for 48 hours. Lipolytic bacteria were enumerated according to Beerens and Luquet (1990) [32]; the plates were incubated at $30^{\circ} \mathrm{C}$ for 4 days. The lipolytic colonies were identified by copper sulphate $(20 \%)$ flooded after incubation. Proteolytic bacteria were counted according to Frank et al. (1992) [33] using plate count agar supplemented with $10 \%$ skim milk powder. The plates were incubated at $30^{\circ} \mathrm{C}$ for 4 days. Yeasts and moulds count were determined according to Tatini et al., (2003) [34], using potato dextrose agar, and the plates were incubated at $25^{\circ} \mathrm{C}$ for 5 days.

\section{Results and Discussion}

\subsection{Sensory Evaluation}

The results of organoleptic scores were illustrated in Table (1). From the data shown in this Table; the best flavor, body and texture was for processed cheese spreads supplemented with $1 \%$ and $1.5 \%$ mushroom powder followed by that contain $2 \%$ mushroom powder and then cheese control. There was a significant differences $(\mathrm{P} \leq 0.01)$ between processed cheese spread treatments in flavor, color and appearance; it was noticed that adding mushroom reduce the color scores, especially mushroom powder (17.4-17.6), which make the color slightly opaque, close results were found by Fatma, et al. (2005) [6]. On the other hand, treatments that contain $1 \%$ and $1.5 \%$ MP had highest flavor scores $(37.4,37.3$, respectively), comparing with control (35.7) and other processed cheese treatments (33.9-35.1). Moreover, there are a little increase in body and texture scores of processed cheese contain 1.5\% MP (37.2), followed by treatment contain 1\% MP (36.5) comparing with cheese control (36.1) and other processed cheese spread treatments (34.1-36.2). This improve in texture of processed cheese 
spread treatments by adding mushroom powder may be related to the polysaccharides which found in mushroom [19, 20]. Color of processed cheese spreads that contain smashed mushroom was close to control. However, the highest total scores were 91, 90.7 and 90.2; for control and treatments that contain $1 \%$ and $2 \%$ mushroom powder, respectively.

\subsection{Chemical Composition}

Data in Table (2) shows moisture, protein /DM, minerals content and $\mathrm{pH}$ in processed cheese treatments. There was a significant difference $(\mathrm{P} \leq 0.05)$ between treatment and during storage period $\left(0,15,30\right.$ and 60 days at $\left.7^{\circ} \mathrm{C}\right)$. There are decreasing in moisture content of all processed cheese treatments during storage period. However, it was noticed that all processed cheese spread treatments supplemented with mushrooms show high moisture content (47.39-53.72\%) comparing to control $(46.26 \%)$, that may related to polysaccharide in mushroom that keep moisture in processed cheese spread also adding fresh mushroom contain high moisture (90.71), which reflected to the moisture content of processed cheese spread. This result was a little close to that obtained by Fatma et al., (2005) [6]. Also these results were close to the findings with Suleiman, et al., (2011) [7] who reported that moisture content of three month old processed cheese was ranged from 49.33-54.17\%. This characteristic of moisture is connected to the initial primary materials and the formulation, which was carried out in compliance with the Code of Federal Regulations (2013) [35], which provides for between $44 \%$ and $60 \%$ for cheese spreads. But the results of moisture were less from what found $(57.33-59.4 \%)$ by Toro et al. (2016) [36].

Table 1. Organoleptic properties of processed cheese spreads supplemented with fresh and dried mushrooms.

\begin{tabular}{lllll}
\hline Treatments & Flavor (40) & Body\&Texture (40) & Color\&Appearance (20) & Total (100) \\
\hline T1 & $35.7^{\mathrm{ab}}$ & $36.1^{\mathrm{a}}$ & $18.4^{\mathrm{a}}$ & $90.2^{\mathrm{a}}$ \\
T2 & $35.1^{\mathrm{ab}}$ & $36.2^{\mathrm{a}}$ & $18.2^{\mathrm{ab}}$ & $89.5^{\mathrm{a}}$ \\
T3 & $34.2^{\mathrm{b}}$ & $34.3^{\mathrm{a}}$ & $16.7^{\text {cde }}$ & $85.2^{\mathrm{a}}$ \\
T4 & $34.4^{\mathrm{b}}$ & $34.8^{\mathrm{a}}$ & $16.8^{\text {cde }}$ & $86.0^{\mathrm{a}}$ \\
T5 & $34.2^{\mathrm{b}}$ & $34.3^{\mathrm{a}}$ & $17.4^{\mathrm{bcd}}$ & $85.9^{\mathrm{a}}$ \\
T6 & $33.9^{\mathrm{b}}$ & $34.1^{\mathrm{a}}$ & $17.6^{\mathrm{abc}}$ & $85.6^{\mathrm{a}}$ \\
T7 & $33.9^{\mathrm{b}}$ & $34.6^{\mathrm{a}}$ & $17.5^{\mathrm{abc}}$ & $86.0^{\mathrm{a}}$ \\
T8 & $37.4^{\mathrm{a}}$ & $36.5^{\mathrm{a}}$ & $16.8^{\mathrm{cde}}$ & $90.7^{\mathrm{a}}$ \\
T9 & $37.3^{\mathrm{a}}$ & $37.2^{\mathrm{a}}$ & $16.5^{\mathrm{de}}$ & $91.0^{\mathrm{a}}$ \\
T10 & $35.9^{\mathrm{ab}}$ & $36.0^{\mathrm{a}}$ & $16.4^{\mathrm{e}}$ & $88.3^{\mathrm{a}}$ \\
SE \pm & 0.92 & 1.06 & 0.312 & 2.12 \\
\hline
\end{tabular}

T1: Control processed cheese spread, T2: Processed cheese spread $+5 \%$ fresh mushroom pieces, T3: Processed $+10 \%$ fresh mushroom pieces, T4: Processed $+15 \%$ fresh mushroom pieces, T5: Processed $+5 \%$ fresh smashed mushroom, T6: Processed $+10 \%$ fresh smashed mushroom, T7: Processed $15 \%$ fresh smashed mushroom, T8: Processed $+1 \%$ mushroom Powder, T9: Processed $+1.5 \%$ mushroom Powder, T10: Processed $+2 \%$ mushroom Powder. Means in the same column with different letters as superscript are significant different $(\mathrm{P} \leq 0.05)$.

Adding mushrooms to the cheese spread increases protein/DM as shown in Table (2). Cheese spreads that contain mushrooms was high in protein/DM (31.20-36.36\%) comparing to the spread of control $(30.88 \%)$. The content of protein was increasing in cheese spreads with increasing the added level of mushroom. The highest value (36.36\%) was for spread contains mushroom powder with level $2 \%$. The increase in protein content of spreads that contain mushrooms may due to high content of this component in mushroom. This result was in agreement with that found by Fatma et al. (2005) [6].

Ash content of different processed cheese spreads were explained in Table (2). There was a significant difference $(\mathrm{P} \leq 0.001)$ in ash content between processed cheese treatments. It is obvious from these results that processed cheese spread that supplemented with fresh and dried mushrooms had higher ash content (4.85-5.4\%) than control $(4.43 \%)$. The highest ash content $(5.4 \%)$ was for processed cheese spread supplemented with $2 \%$ dried mushroom, that mainly due to that mushroom powder had high content of ash (6.68). These results were in agreement with that found by Fatma et al., (2005) [6], where they reported that ash was $5.1-5.36 \%$ during storage of processed cheese spreads made with fresh mushroom.
The $\mathrm{pH}$ values for processed cheese spreads were explained in Table (2); there was a significant difference $(\mathrm{P} \leq$ $0.05)$ in $\mathrm{pH}$ values between treatments of processed cheese spreads. The $\mathrm{pH}$ values in all treatments were decreasing during storage period, regarding the $\mathrm{pH}$ values of spreads contain mushrooms ranged from 5.39-5.78 and it was noticed that treatments supplemented with mushroom powder was the highest $\mathrm{pH}$ values (Table 2), while, in control ranged from 5.47-5.63. These $\mathrm{pH}$ values in agreement with what obtained by Mohamed et al., (2011) [1]; they found that the $\mathrm{pH}$ values were, 5.75 and 5.78 in processed cheese made from cow and goat milk, respectively. Also our results close to what found by Fatma, et al. (2005) [6], whereas the $\mathrm{pH}$ in their study during storage ranged from 5.75-5.97.

The previous chemical composition of different processed cheese spreads in this work was in agreement with what reported by many investigators in their work; protein 12.82 22.6, moisture 38.2-64.21\%, ash 1.33 - 5.64, and $\mathrm{pH} 4.4$ 6.3 depending on the ingredients used in the manufacture of cheese [8-11, 36].

Minerals content of processed cheese spreads samples were given in Table (2). There was a significant difference ( $P$ $\leq 0.001$ ) in the contents of all tested minerals in processed cheeses. The highest mean values of $\mathrm{Ca}, \mathrm{P}$ and $\mathrm{Mg}$ were 
observed in control and processed cheese that contain MP. However, control of processed cheese spreads was slightly higher in $\mathrm{Ca}, \mathrm{P}$ and $\mathrm{Mg}$ than other processed cheese treatments. All processed cheese spread supplemented with mushroom powder at levels of $1,1.5$ and $2 \%$ was higher in potassium content (95.93, 100.24 and $116.67 \mathrm{mg} / 100 \mathrm{~g}$, respectively) than cheese control (83.16) and cheese that contain fresh mushrooms, this may be due to high potassium content in added mushroom powder [14] and also the lower moisture content in it than fresh mushroom. Moreover, the highest mean values of $\mathrm{Fe}$ and $\mathrm{Zn}$ were detected in cheese spread contains $2 \%$ MP.

Table 2. Gross chemical composition and mineral contents of processed cheese spreads supplemented with fresh and dried mushrooms during different storage period.

\begin{tabular}{|c|c|c|c|c|c|c|c|c|c|c|c|}
\hline \multirow{2}{*}{$\begin{array}{l}\text { Gross } \\
\text { composition (\%) }\end{array}$} & \multicolumn{11}{|c|}{ Processed cheese spread treatments } \\
\hline & T1 & $\mathbf{T 2}$ & T3 & T4 & T5 & T6 & $\mathbf{T 7}$ & T8 & T9 & T10 & $\mathbf{S E} \pm$ \\
\hline Protein & $16.59^{\mathrm{D}}$ & $14.84^{\mathrm{J}}$ & $15.17^{\mathrm{I}}$ & $15.33^{\mathrm{H}}$ & $15.37^{\mathrm{G}}$ & $15.85^{\mathrm{F}}$ & $16.12^{\mathrm{E}}$ & $17.35^{\mathrm{C}}$ & $17.86^{\mathrm{B}}$ & $18 .^{\mathrm{A}}$ & .004 \\
\hline Ash & $4.43^{\mathrm{G}}$ & $4.85^{\mathrm{F}}$ & $4.95^{\mathrm{E}}$ & $5.14^{\mathrm{c}}$ & $4.91^{\mathrm{ef}}$ & $5.05^{\mathrm{D}}$ & $5.23^{\mathrm{B}}$ & $5.23^{\mathrm{B}}$ & $5.36^{\mathrm{A}}$ & $5.4^{\mathrm{A}}$ & 0.023 \\
\hline DM & 53.74 & 47.74 & 47.36 & 46.28 & 49.35 & 48.79 & 48.25 & 52.61 & 52.27 & 50.06 & \\
\hline Protein/DM & 30.88 & 31.20 & 32.03 & 33.13 & 31.5 & 32.49 & 33.4 & 32.98 & 34.16 & 36.36 & \\
\hline \multicolumn{12}{|c|}{ Minerals Content $(\mathrm{mg} / 100 \mathrm{~g})$ in processed cheese spreads } \\
\hline $\mathrm{Ca}$ & $351.55^{\mathrm{A}}$ & $317.67^{\mathrm{B}}$ & $264.44^{\mathrm{H}}$ & $260.27^{\mathrm{I}}$ & $286.54^{\mathrm{E}}$ & $272.70^{\mathrm{F}}$ & $270.64^{\mathrm{G}}$ & $302.10^{\mathrm{C}}$ & $300.52^{\mathrm{C}}$ & $290.40^{\mathrm{D}}$ & 0.67 \\
\hline $\mathrm{K}$ & $83.16^{\mathrm{F}}$ & $68.45^{\mathrm{I}}$ & $80.56^{\mathrm{G}}$ & $82.96^{\mathrm{F}}$ & $78.41^{\mathrm{H}}$ & $86.99^{\mathrm{E}}$ & $89.89^{\mathrm{D}}$ & $95.93^{\mathrm{C}}$ & $100.24^{\mathrm{B}}$ & $116.67^{\mathrm{A}}$ & 0.21 \\
\hline $\mathrm{Mg}$ & $12.42^{\mathrm{A}}$ & $9.74^{\mathrm{F}}$ & $9.43^{\mathrm{G}}$ & $11.42^{\mathrm{D}}$ & $9.71^{\mathrm{F}}$ & $10.49^{\mathrm{E}}$ & $10.47^{\mathrm{E}}$ & $11.67^{\mathrm{C}}$ & $11.84^{\mathrm{B}}$ & $11.86^{\mathrm{B}}$ & 0.04 \\
\hline $\mathrm{Zn}$ & $0.633^{\mathrm{B}}$ & $0.471^{\mathrm{G}}$ & $0.510^{\mathrm{F}}$ & $0.656^{\mathrm{A}}$ & $0.62^{\mathrm{C}}$ & $0.613^{C D}$ & $0.638^{\mathrm{B}}$ & $0.577^{\mathrm{e}}$ & $0.608^{\mathrm{D}}$ & $0.664^{\mathrm{A}}$ & 0.003 \\
\hline $\mathrm{Fe}$ & $0.177^{\mathrm{H}}$ & $0.25^{\mathrm{G}}$ & $0.282^{\mathrm{F}}$ & $0.394^{\mathrm{D}}$ & $0.176^{\mathrm{H}}$ & $0.259^{\mathrm{G}}$ & $0.343^{\mathrm{E}}$ & $0.44^{\mathrm{C}}$ & $0.50^{\mathrm{B}}$ & $0.554^{\mathrm{A}}$ & 0.005 \\
\hline Age & Moisture & & & & & & & & & & 0.34 \\
\hline Fresh & $46.26^{\mathrm{vwx}}$ & $52.26^{\text {bcd }}$ & $52.64^{\mathrm{bc}}$ & $53.72^{\mathrm{a}}$ & $50.65^{\text {efghi }}$ & $51.21^{\operatorname{defg}}$ & $51.75^{\text {bcde }}$ & $47.39^{\text {rstu }}$ & $47.73^{\mathrm{pqrst}}$ & $49.94^{\text {hijkl }}$ & \\
\hline 15 day & $45.90^{\mathrm{vwxy}}$ & $49.65^{\mathrm{ijklm}}$ & $51.57^{\text {cde }}$ & $52.70^{\mathrm{b}}$ & $48.67^{\mathrm{mnop}}$ & $50.12^{\text {ghijk }}$ & $50.98^{\text {efgh }}$ & $46.77^{\text {stuv }}$ & $47.47^{\text {qrstu }}$ & $48.92^{1 \mathrm{mno}}$ & \\
\hline 30 day & $45.14^{y}$ & $47.8^{\mathrm{pqrs}}$ & $51.34^{\mathrm{def}}$ & $51.73^{\text {bcde }}$ & $47.73^{\text {pqrst }}$ & $49.49^{\mathrm{jklmn}}$ & $50.37^{\text {fghij }}$ & $46.00^{\mathrm{vwxy}}$ & $46.51^{\mathrm{uvw}}$ & $48.09^{\text {opqr }}$ & \\
\hline Age & $\mathrm{pH}$ & & & & & & & & & & 0.01 \\
\hline Fresh & $5.63^{\mathrm{cd}}$ & $5.7^{\mathrm{b}}$ & $5.64^{\mathrm{c}}$ & $5.49^{\mathrm{jklm}}$ & $5.64^{\mathrm{c}}$ & $5.52^{\text {ghij }}$ & $5.48^{\mathrm{jklm}}$ & $5.78^{\mathrm{a}}$ & $5.777^{\mathrm{a}}$ & $5.69^{b}$ & \\
\hline 15 day & $5.57^{\mathrm{ef}}$ & $5.63^{\mathrm{b}}$ & $5.51^{\text {hijk }}$ & $5.48^{\mathrm{klmn}}$ & $5.62^{\mathrm{cd}}$ & $5.47^{\mathrm{klmn}}$ & $5.45^{\mathrm{Imno}}$ & $5.777^{\mathrm{a}}$ & $5.62^{\mathrm{cd}}$ & $5.61^{\mathrm{ecd}}$ & \\
\hline 30 day & $5.56^{\mathrm{ef}}$ & $5.58^{\mathrm{e}}$ & $5.46^{\mathrm{Imno}}$ & $5.45^{\mathrm{mnop}}$ & $5.61^{\mathrm{cd}}$ & $5.43^{\text {mnop }}$ & $5.44^{\mathrm{mno}}$ & $5.70^{\mathrm{b}}$ & $5.57^{\mathrm{ef}}$ & $5.56^{\mathrm{ef}}$ & \\
\hline 60 day & $5.47^{\mathrm{jklm}}$ & $5.53^{\mathrm{i}}$ & $5.42^{\mathrm{op}}$ & $5.39^{q}$ & $5.55^{\mathrm{fgh}}$ & $5.43^{\text {mnop }}$ & $5.43^{\mathrm{mnop}}$ & $5.697^{\mathrm{b}}$ & $5.48^{\mathrm{klmn}}$ & $5.45^{\mathrm{Imno}}$ & \\
\hline
\end{tabular}

T1: Control processed cheese spread, T2: Processed cheese spread $+5 \%$ fresh mushroom pieces, T3: Processed $+10 \%$ fresh mushroom pieces, T4: Processed $+15 \%$ fresh mushroom pieces, T5: Processed $+5 \%$ fresh smashed mushroom, T6: Processed $+10 \%$ fresh smashed mushroom, T7: Processed 1 5\% fresh smashed mushroom, T8: Processed $+1 \%$ mushroom Powder, T9: Processed $+1.5 \%$ mushroom Powder, T10: Processed $+2 \%$ mushroom Powder. Means of protein, ash $\%$ and minerals content in the same raw with different letters are significant different $(\mathrm{P} \leq 0.001)$, While, means of Moisture $\%$ and $\mathrm{pH}$ in the column with different letters are significant different $(\mathrm{P} \leq 0.05)$.

Data in Table (3) show amino acid content of processed cheese spreads; it was noticed that there was a little differences between amino acid content in processed cheese supplemented with MP and that in control. However, there were an increase in glutamic, proline, and leucin in all processed cheese treatments than the other amino acids and it increases more in control and treatments that supplemented with MP than FM; that may revealed to higher moisture content of processed cheese treatments that contain fresh mushroom, which may affect the level of amino acids concentration. These results were not similar to what found by Toro et al. (2016) [36]; who found that concentrations of Leucine, Iso leucine, Phenylalanine, Methionine, and Valine were $2041.4,1003.07,935.823,758.3$ and $475.3 \mathrm{mg} / 100 \mathrm{~g}$, respectively.

\subsection{Microbiological Quality of Processed Cheese Spreads}

Changes in microbiological quality during storage of processed cheese spreads supplemented with fresh and dried mushrooms were shown in Table (4). In all fresh cheese samples total viable count was very little and there was no growth for yeast and moulds during first 30 days of storage; this may be due to the heat treatment used during preparing of processed cheese spreads. In the overall results observed a decrease in the number of most tested microorganisms in all processed cheese treatments in comparison to that obtained in cheese control. An increase in the total bacterial count was observed along storage period. Total bacterial count for processed cheese treatments containing fresh mushroom pieces and smashed, was ranged from 1.22 to $3.16 \log \mathrm{cfu} / \mathrm{g}$. On the other hand viable counts in mushroom powder were 1.76-3.88 $\log \mathrm{cfu} / \mathrm{g}$, while the control ranged from 2.89 to 4.6 $\log \mathrm{cfu} / \mathrm{g}$. Muir et al. (1999) [37] reported that a slight reduction in bacterial count was observed by the end of 4 months storage, while in this study slightly higher it was at the end of the storage period of 90 days in all treatments during storage.

Table 3. Total amino acid content of processed cheese spreads supplemented with fresh and dried Mushrooms.

\begin{tabular}{llll}
\hline \multirow{2}{*}{ Amino acid } & \multicolumn{3}{l}{ Total amino acids \% } \\
\cline { 2 - 4 } & T1 & T6 & T9 \\
\hline Aspartic & 3.36 & 2.75 & 3.04 \\
Therionine & 1.83 & 1.34 & 1.79 \\
Serine & 2.40 & 1.67 & 2.23 \\
Glutamic & 8.47 & 6.60 & 7.80 \\
Glycine & 0.91 & 0.79 & 0.96 \\
Alanine & 1.41 & 1.17 & 1.46 \\
\hline
\end{tabular}




\begin{tabular}{llll}
\hline \multirow{2}{*}{ Amino acid } & \multicolumn{3}{l}{ Total amino acids \% } \\
\cline { 2 - 4 } & T1 & T6 & T9 \\
\hline Valine & 2.90 & 2.37 & 2.89 \\
Isoleucine & 2.48 & 2.00 & 2.56 \\
Leucine & 4.36 & 3.48 & 4.40 \\
Tyrosine & 2.61 & 2.19 & 2.74 \\
Phenylalanine & 2.61 & 2.12 & 2.77 \\
Histidine & 1.75 & 1.45 & 1.82 \\
Lysine & 3.50 & 2.87 & 3.55 \\
Arginine & 1.73 & 1.50 & 1.86 \\
Proline & 4.83 & 3.74 & 4.81 \\
Cystine & 0.27 & 0.52 & 0.36 \\
Methionine & 1.10 & 0.92 & 1.20 \\
\hline
\end{tabular}

T1: Control processed cheese spread, T6: Processed $+10 \%$ fresh smashed mushroom, T9: Processed $+1.5 \%$ mushroom Powder

Regarding aerobic spore former bacteria data in Table (4) shows that there was a decrease in the numbers of spore forming bacteria, for all processed cheese treatments supplemented with mushrooms compared with control during storage for 3 months at $\left(7^{\circ} \mathrm{C}\right)$, this is similar to what found by Aly et al. (1995) [38]. Changes in proteolytic and lipolytic bacteria in processed cheese supplemented with mushrooms were explained in Table (4). The proteolytic bacterial counts was ranged from $0.54-1.46,0.32-1.42,0.57-1.52$ and 0.57 $1.33 \mathrm{log} \mathrm{cfu} / \mathrm{g}$ for processed with; mushroom pieces, mashed mushroom, mushroom powder and processed cheese control, respectively. While, counts of lipolytic bacteria; ranged from, $0.21-0.99,0.33-1.01,0.21-1.18$ and $0.39-0.96 \log \mathrm{cfu} / \mathrm{g}$, for previous treatments, respectively. A slight reduction in the total bacterial counts was observed along storage period may be due decreasing in moisture content. There was no growth noticed for yeast and moulds in all processed cheese treatments during the first month of storage at $7^{\circ} \mathrm{C}$; this is attributed to the thermal heating of blends, and the counts recorded in all cheese treatments was low after 90 days of storage period (Table 4). The detected counts ranged from (1.45-1.57 cfu/gm) in cheese treatments supplemented with mushrooms, while, it was higher $(1.90 \mathrm{cfu} / \mathrm{gm})$ in the cheese control. These results were disagreement was what found by Mohamed (2004) [39]; who found that processed cheese were free from yeasts and moulds during storage at $5^{\circ} \mathrm{C}$ or $25^{\circ} \mathrm{C}$.

Table 4. Microbiological quality ( $\left.\log _{10} \mathrm{cfu} / \mathrm{gm}\right)$ during storage period of processed cheese spreads supplemented with fresh and dried mushrooms.

\begin{tabular}{|c|c|c|c|c|c|c|}
\hline \multirow{2}{*}{ Treatments } & \multirow{2}{*}{ Storage period (day) } & \multicolumn{5}{|c|}{ Microbiological count $\left(\log _{10} \mathrm{cfu} / \mathrm{gm}\right)$} \\
\hline & & Total count bacteria & Spore forming bacteria & Proteolytic bacteria & Lipolytic bacteria & Yeast and mold \\
\hline \multirow{5}{*}{$\mathrm{T} 1$} & Fresh & 0.00 & 0.00 & 0.00 & 0.00 & 0.00 \\
\hline & 7 & 2.89 & 0.14 & 0.57 & 0.39 & 0.00 \\
\hline & 15 & 3.40 & 0.37 & 0.86 & 0.52 & 0.00 \\
\hline & 30 & 3.70 & 1.12 & 1.33 & 0.74 & 0.00 \\
\hline & 90 & 4.60 & 2.44 & 0.69 & 0.96 & 1.90 \\
\hline \multirow{5}{*}{$\mathrm{T} 2$} & Fresh & 0.00 & 0.00 & 0.00 & 0.00 & 0.00 \\
\hline & 7 & 1.76 & 0.04 & 0.50 & 0.33 & 0.00 \\
\hline & 15 & 1.99 & 0.27 & 0.76 & 0.54 & 0.00 \\
\hline & 30 & 2.11 & 1.08 & 1.19 & 0.96 & 0.00 \\
\hline & 90 & 2.80 & 2.24 & 0.67 & 1.01 & 1.45 \\
\hline \multirow{5}{*}{$\mathrm{T} 3$} & Fresh & 0.00 & 0.00 & 0.00 & 0.00 & 0.00 \\
\hline & 7 & 1.22 & 0.11 & 0.32 & 0.39 & 0.00 \\
\hline & 15 & 2.00 & 0.49 & 0.68 & 0.50 & 0.00 \\
\hline & 30 & 2.72 & 1.22 & 1.02 & 0.94 & 0.00 \\
\hline & 90 & 2.89 & 2.2 & 0.93 & 0.96 & 1.55 \\
\hline \multirow{5}{*}{$\mathrm{T} 4$} & Fresh & 0.00 & 0.00 & 0.00 & 0.00 & 0.00 \\
\hline & 7 & 2.22 & 0.23 & 0.42 & 0.41 & 0.00 \\
\hline & 15 & 2.60 & 1.01 & 0.66 & 0.52 & 0.00 \\
\hline & 30 & 2.76 & 1.14 & 1.42 & 0.74 & 0.00 \\
\hline & 90 & 3.16 & 2.05 & 0.99 & 1.11 & 1.57 \\
\hline \multirow{5}{*}{ T5 } & Fresh & 0.00 & 0.00 & 0.00 & 0.00 & 0.00 \\
\hline & 7 & 1.74 & 0.52 & 0.84 & 0.21 & 0.00 \\
\hline & 15 & 2.80 & 0.73 & 1.03 & 0.42 & 0.00 \\
\hline & 30 & 2.76 & 1.2 & 1.52 & 0.61 & 0.00 \\
\hline & 90 & 3.16 & 2.4 & 1.00 & 0.89 & 1.45 \\
\hline \multirow{5}{*}{ T6 } & Fresh & 0.00 & 0.00 & 0.00 & 0.00 & 0.00 \\
\hline & 7 & 1.77 & 0.43 & 0.57 & 0.46 & 0.00 \\
\hline & 15 & 2.34 & 1.00 & 0.84 & 0.66 & 0.00 \\
\hline & 30 & 2.76 & 1.70 & 1.30 & 0.98 & 0.00 \\
\hline & 90 & 3.16 & 2.11 & 0.79 & 1.12 & 1.42 \\
\hline \multirow{5}{*}{$\mathrm{T} 7$} & Fresh & 0.00 & 0.00 & 0.00 & 0.00 & 0.00 \\
\hline & 7 & 1.79 & 0.78 & 0.74 & 0.62 & 0.00 \\
\hline & 15 & 2.1 & 0.97 & 0.86 & 0.78 & 0.00 \\
\hline & 30 & 2.79 & 1.30 & 1.30 & 0.97 & 0.00 \\
\hline & 90 & 3.00 & 1.69 & 0.80 & 1.18 & 1.46 \\
\hline \multirow{5}{*}{ T8 } & Fresh & 0.00 & 0.00 & 0.00 & 0.00 & 0.00 \\
\hline & 7 & 1.78 & 0.43 & 0.87 & 0.42 & 0.00 \\
\hline & 15 & 2.14 & 0.51 & 1.11 & 0.72 & 0.00 \\
\hline & 30 & 2.82 & 1.14 & 1.38 & 0.94 & 0.00 \\
\hline & 90 & 3.40 & 1.39 & 1.00 & 0.97 & 1.57 \\
\hline
\end{tabular}




\begin{tabular}{|c|c|c|c|c|c|c|}
\hline \multirow{2}{*}{ Treatments } & \multirow{2}{*}{ Storage period (day) } & \multicolumn{5}{|c|}{ Microbiological count $\left(\log _{10} \mathrm{cfu} / \mathrm{gm}\right)$} \\
\hline & & Total count bacteria & Spore forming bacteria & Proteolytic bacteria & Lipolytic bacteria & Yeast and mold \\
\hline \multirow{5}{*}{ T9 } & Fresh & 0.00 & 0.00 & 0.00 & 0.00 & 0.00 \\
\hline & 7 & 1.76 & 0.42 & 0.54 & 0.21 & 0.00 \\
\hline & 15 & 2.97 & 1.00 & 0.88 & 0.41 & 0.00 \\
\hline & 30 & 3.33 & 1.48 & 1.30 & 0.52 & 0.00 \\
\hline & 90 & 3.66 & 1.89 & 0.89 & .99 & 1.57 \\
\hline \multirow{5}{*}{$\mathrm{T} 10$} & Fresh & 0.00 & 0.00 & 0.00 & 0.00 & 0.00 \\
\hline & 7 & 2.81 & 0.32 & 0.57 & 0.41 & 0.00 \\
\hline & 15 & 2.98 & 0.57 & 0.81 & 0.62 & 0.00 \\
\hline & 30 & 3.36 & 1.18 & 1.46 & 0.74 & 0.00 \\
\hline & 90 & 3.88 & 2.00 & 1.00 & 0.97 & 1.57 \\
\hline
\end{tabular}

T1: Control processed cheese spread, T2: Processed cheese spread $+5 \%$ fresh mushroom pieces, T3: Processed $+10 \%$ fresh mushroom pieces, T4: Processed $+15 \%$ fresh mushroom pieces, T5: Processed $+5 \%$ fresh smashed mushroom, T6: Processed $+10 \%$ fresh smashed mushroom, T7: Processed $15 \%$ fresh smashed mushroom, T8: Processed $+1 \%$ mushroom Powder, T9: Processed $+1.5 \%$ mushroom Powder, T10: Processed $+2 \%$ mushroom Powder.

\section{Conclusions}

Incorporation of processed cheese spreads with fresh and dried mushrooms, resulted in a product with good functional, compositional, sensorial and microbiological qualities. Whereas, nutrients components increased; minerals, protein/DM was ranged from 31.20 to $36.36 \%$ and the amino acid content is good enough to introduce a notable food product in terms of nutrition for different groups of people due to its versatility and ease of consumption. It is also noted that adding mushroom powder improves flavor and texture of the processed cheese. The microbiological examination of processed cheese revealed good hygienic quality of the processed cheese under study that might be due to the heat treatment of cheese and also the antibacterial effect of mushroom.

\section{References}

[1] A. G. Mohamed, A. M. H. Fatma, M. B. Hala and K. E. Ali. Utilization of goat's milk in manufacture of processed cheese. Journal of American Science, 2011, 7 (7), 616-621.

[2] R. Kapoor and L. Metzger. Process Cheese and Technological Aspects: A review. Comprehensive Reviews in Food Science and Food Safety, 2008, 7, 194-214.

[3] R. A, Awad. Impact of potato puree as a cheese base replacement in manufacture of proceesed cheese. Egyptian J. Dairy Sci., 2003, 31, 375.

[4] H. K. Mayer. Bitterness in processed cheese caused by an overdose of a specific emulsifying agent. Int. Dairy J., 2001, $11: 533-542$

[5] W. Schär, and J. O. Bosset. Chemical and physico- chemical changes in processed cheese and ready- made fondue during storage. A review. Lebensm.- Wiss. U.-Technol, 2002, 35: 1520.

[6] A. F. Fatma, A. M. H Gehan, and A. G. Mohammed. Fortification of processed cheese spread with accustomed edible mushroom. Arab Univ. J. Agric. Sci., 2005, 13 (3), 825839.

[7] T. A Suleiman, O. M. A Mohamed, H. M. El Nissreen, and M. $\mathrm{O}$ Elsiddig. Chemical and microbiological evaluation of processed cheese available in Khartoum market, Sudan American Journal of Food and Nutrition, 2011, 1 (1): 28-33.

[8] M. R. Acharya, and V. V Mistry. Effect of vacuum- condensed or ultrafiltered milk on pasteurized process cheese. J. Dairy Sci., 2005, 88: 3037-3043.

[9] R. Kapoor, L. E. Metzger, A. C Biswas and K. Muthukummarappan, Effect of natural cheese characteristics on process cheese properties. J. Dairy Sci., 2007, 90: 16251634 .

[10] N. Shirashoji, J. J Jaeggi, and J. A. Lucey, Effect of trisodium citrate concentration and cooking time on the physicochemical properties of pasteurized process cheese. J. Dairy Sci., 2006, 89: $15-28$.

[11] S. Pinto, A. K. Rathour, J. P. Prajapati, A. H Jana and M. J. Solanky. Utilization of whey protein concentrate in processed cheese spread. Natural Product Radiance, 2007, 6 (5): 398401 .

[12] J. L. Priya and V. Srinivasan. Studies on the antibacterial activities of mushroom. Int. J. Curr. Microbiol. App. Sci, 2013, 2 (6): 184-189.

[13] B. L. Chelela,, M. Chacha, and A. Matemu. Antibacterial and antifungal activities of selected wild mushrooms from Southern Highlands of Tanzania. American Journal of Research Communication, 2014, 2 (9): 58-58.

[14] R. H. Jr. Kurtzman. Mushrooms: Sources for modern western medicin. Micologia Aplicada International, 2005, 17 (2): pp. 21-33.

[15] M. Kosanić, B. Ranković, and M. Dašić. Mushrooms as Possible Antioxidant and Antimicrobial Agents. Iranian Journal of Pharmaceutical Research, 2012, 11 (4), 1095-1102.

[16] J. C. Okafor, G. I. Okafor, A. U. Ozumba and G. N. Elemo. Quality characteristics of bread made from wheat and Nigerian oyster mushroom (Pleurotus plumonarius) Powder, 2012, Pak. J. Nutr., 11: 510.

[17] S. Khatun, A. Islam, U. Cakilcioglu, and N. C. Chatterjee. Research on Mushroom as a Potential Source of Nutraceuticals: A Review on Indian Perspective American Journal of Experimental Agriculture, 2012, 2 (1): 47-73.

[18] Y. Patel, R. Naraian, V. K. Singh. Medicinal Properties of Pleurotus Species (Oyster Mushroom): A Review. World J. Fungal Plant Biol., 2012, 3: 01-12. 
[19] M. J., Alves, I. C. F. R., Ferreira, J., Dias, V. Teixeira, A. Martins, and M., Pintado. A Review on antifungal activity of mushroom (Basidiomycetes) extracts and isolated compounds. Current Topics in Medicinal Chemistry, 2013, 13, 2648-2659.

[20] K. S., Arvind, A. M., Jana, A., Srivastav, M., Gupta, S. Sharma, S. S, Gill. Antimicrobial properties of some edible mushrooms: A Review. World Journal of Phrmacy and Pharmaceutical Sciences, 2014, 3 (5): 1009-1023.

[21] M. Khider, K. Elbanna, O. Seoudi, and A. El-Fakharany. Lactic Acid Fermented Permeates and Mushroom Powder (Pleurotus ostreatus $\mathrm{Hk}$ 35) for Improvement of the Nutritional Value and Quality of Pan Bread. Int. J. Curr. Microbiol. App. Sci, 2015, 4 (8): 723-736.

[22] A. Meyer. In: Processed cheese Manufacture, 1973, $1^{\text {st }}$ ed., pp 98-277. Food Trade Press Ltd., London, UK.

[23] AOAC. 2000, Official Methods of Analysis of AOAC International, $17^{\text {th }}$ edn., AOAC International, Gaitherburg, MD, USA, Official Methods 920.124, 926.08, 995.30, 20001.14. Washington, DC, USA.

[24] P Peláez, M Fresno, C Días and J Darias. Caracterización físico-química de quesos frescos elaborados con leche de cabra en la isla de Tenerife. Ciencia y Tecnología Alimentaria, 2003, 4 (2): 103-108.

[25] APHA AWWA, WEF APHA. Standard methods for the examination of water and wastewater. 3120 "B" Inductively Coupled Plasma (ICP) Method, American Public Health Association, Washington, D. C., 2005, Pp. 3-44.

[26] AOAC. Association of Official Analytical Chemists. Official methods of analysis. $19^{\text {th }}$ edn., 2012, p 18-19.

[27] SPSS. Statistical Package for Social Sciences. SPSS Inc., 1999, 444, North Michigen Avenue, Chicago, IL 606 11, USA.

[28] D. B. Duncan. Multiple range and Multiple F test. Biometr., 1955, 11: 142 .

[29] T. R. Marshall, Standard methods for the examination of dairy products, $16^{\text {th }}$ edn. American Public Health Association, Washington, U. S. A, 1992, pp 433-531.

[30] A. G. Houghtby, L. J Maturin and K. E Koenig.
Microbiological count methods. In: Marshall RT (editor), Standard Methods for the Examination of Dairy Products, $16^{\text {th }}$ edition, Ed. Washington, DC: American Public Health Association, 1992, pp 213-246.

[31] R. L. Richter, R. A. Ledford and S. C. Murphy. Methods for the Microbiological Examinationof Foods. In: Vanderzant $\mathrm{C}$ and Splittstoesser DF (eds.) 3rd ed. (American Public Health Association, Washington DC) chap., 1992, 45, pp. 837-856.

[32] H. Beerners, and F. M. Luquet. Practical guide for microbiological analyses of milk and dairy products. Zaragoza, Editorial Acríbia, S. A., 1990.

[33] F. J. Frank, L. G. Christen and L. B Bullerman. Tests for groups of microorganisms. In: Marshall RT (ed): Standard Methods for the Examination of Dairy Products, $16^{\text {th }}$ edition, Ed. Washington, DC: American Public Health Association, 1992, pp 271-286.

[34] S. R. Tatini and K. L. Kauppi. Encyclopedia of Dairy Sciences. In: Roginski H, Fuquay JW and Fox PF (eds.) Vol. 1. Academic Press and Elsevier Science, Amsterdam, Boston, London, New York, Oxford, Paris, San Diego, San Francisco, Singapore, Sydney, Tokyo. 2003, pp. 74-79.

[35] FDA (Food and Drug Administration), 2013, 21 CFR, Part 133.179. Food and Drug Administration. Washington, D. C.: Dept. of Health and Human Services.

[36] E. E. B. Toro, J. U. S. Valencia, and D. A. R. Molina. Characterization of a processed cheese spread. Rev. Fac. Nac. Agron, 2016, 69 (2): 8015-8022.

[37] D. D. Muir, A. Y., Tamime, M. E. Shenana and A. H. Dawood. Processed cheese analogue incorporating fat substitutes. 1. Composition, microbiological quality and flavor changes during storage at $5^{\circ} \mathrm{C}$. Lebensmittel- Wissenschaft ündTechnologie, 1999, 32 (1): 41-49.

[38] M. E. Aly, A. A. Abdel-Baky and S. M. Farahat. Quality of Processed Cheese Spread Made Using Ultrafiltered Retentates Treated with some Ripening Agents. International Dairy Journal, 1995, 2 (5): p191-209.

[39] A. G. Mohamed. Studies on spreadable processed cheese emulsifying salts. Ph. D. Thesis Faculty Agric., Cairo University, Cairo, Egypt, 2004. 